\title{
7: 115906410-116032391
}

National Cancer Institute

\section{Source}

National Cancer Institute. 1:115906410-116032391. NCI Thesaurus. Code C41973.

Physical location of C-MET_Gene 